\title{
XYLANASE PRODUCTION WITH XYLAN RICH LIGNOCELLULOSIC WASTES BY A LOCAL SOIL ISOLATE OF TRICHODERMA VIRIDE
}

\author{
Meenakshi Goyal'; K.L. Kalra² ${ }^{2}$ V.K. Sareen ${ }^{1}$; G. Soni1 ${ }^{\text {* }}$ \\ ${ }^{1}$ Department of Biochemistry \& Chemistry, Punjab Agricultural University, Ludhiana, India; ${ }^{2}$ Department of Microbiology, \\ Punjab Agricultural University, Ludhiana, India
}

Submitted: March 26, 2007; Returned to authors for corrections: July 22, 2007; Approved: July 15, 2008.

\begin{abstract}
In the present study, cultural and nutritional conditions for enhanced production of xylanase by a local soil isolate of Trichoderma viride, using various lignocellulosic substrates in submerged culture fermentation have been optimized. Of the lignocellulosics used, maize straw was the best inducer followed by jowar straw for xylanase production. The highest activity achieved was between 14 to 17 days of fermentation. A continuous increase in xylanase production was observed with increasing level of lignocellulosics in the medium and highest activity was observed with maize straw at $5 \%$ level. Xylanase production with higher levels of lignocellulosics ( 3 to 5\%) of maize, jowar and barseem was found to be higher as compared to that with commercial xylan as carbon source. Sodium nitrate was the best nitrogen source among the six sources used. Maximum xylanase production was achieved with initial medium $\mathrm{pH}$ of 3.5-4.0 and incubation temperature of $25^{\circ} \mathrm{C}$. The enzyme preparation was effective in bringing about saccharification of different lignocellulosics. The xylanase production could be further improved by using alkali treated straw as carbon source.
\end{abstract}

Key-words: Xylanase production, Trichoderma viride, Lignocellulosics, Submerged fermentation.

\section{INTRODUCTION}

Xylanases (E.C.2.8.1.8), a group of hemicellulolytic enzymes, are required for the hydrolyisis of $\beta 1,4$-xylans present in lignocellulosic materials (9). Xylanases are the microbial enzymes that have aroused great interest recently due to their potential application in many industrial processes viz; production of hydrolysates from agro-industrial wastes $(6,9)$, nutritional improvement of lignocellulosic feed stuff (25), clarification of juices and wines (4) and biobleaching of craft pulp in paper industry (26).

Xylanases are the extracellular enzymes produced by microorganisms such as bacteria, fungi and some yeasts. The high cost of production of these enzymes, however, has hindered the industrial applications of xylan bioconversion. Lignocellulosic substrates, being cheap and readily available, have recently gained considerable interest because of their possible use in secondary fermentation processes. The ability of various Trichoderma spp. to produce xylanases on various lignocellulosics has been reported $(7,19,20,22)$. This paper presents the potential of a local soil isolate of Trichoderma viride (S 34), to produce xylanase on various feed stuffs like wheat straw, maize straw, bajra straw, oat hay, barseem hay and jowar straw under submerged fermentation conditions $(\mathrm{SmF})$. The attempts have been made to replace xylan, a costly substrate for xylanases production, to make xylanase production cost effective. A number of studies have already been done on lignocellulosic wastes mainly wheat bran $(5,11,15)$, sugarcane bagasse (8) and untreated and treated wheat straw (2) using solid substrate fermentation (SSF) or submerged culture fermentation $(\mathrm{SmF})$. The purpose of this research was to evaluate xylanase production by using various waste lignocellulosic materials as substitutes of xylan and optimizing culture conditions to make its production cost effective under submerged state fermentation.

*Corresponding Author. Mailing address: Department of Biochemistry \& Chemistry Punjab Agricultural University, Ludhiana 141 004, India. Phone No.: + 911612401960 ext 322. E-mail: giridharsoni@rediffmail.com 


\section{MATERIALAND METHODS}

Microorganism selection: Anumber of Trichoderma species were isolated with the association of Department of Microbiology, PAU, Ludhiana and screened for xylanase production along with two standard strains of T. reesei MTCC 164 and T. viride MTCC 1763. These isolates were tested for production of xylanases on Czapek yeast extract media containing $1 \%$ oat spelt xylan as carbon source. Only a laboratory isolate of T. viride (S34), showing good response with respect to xylanase production, was used for further studies. The strain was maintained and sub cultured fortnightly on potato dextrose agar (PDA) slants and stored at $4^{\circ} \mathrm{C}$.

Substrates: Natural lignocellulosics (agricultural biomass) namely bajra straw, wheat straw, maize straw, barseem hay, oat hay and jowar straw were dried in an oven and ground in a Wiley Mill to pass through $1 \mathrm{~mm}$ screen and utilized as substrates for SmF. All the lignocelluloses were passed through filters of same mesh size to provide equal surface area for fungus to grow so that xylanase activity among the lignocellulosics would not differ due to different oxygen diffusion, nutrient absorption and assimilation by mycelia.

Composition of substrates: The lignocellulosics were analysed for crude protein $(\mathrm{CP})$ and organic matter $(\mathrm{OM})$ as per AOAC methods (3), whereas neutral detergent fibre (NDF) and acid detergent fibre (ADF) were analysed by the methods of Van Soest (24).

Fermentation of substrate for xylanase production: The ability of the fungus to utilize different lignocellulosics at the rate of 1 to $5 \%$ as sole carbon sources was examined in Czapek yeast extract medium containing $0.5 \%$ of yeast extract. The 250 $\mathrm{ml}$ cotton plugged conical flasks containing $50 \mathrm{ml}$ medium were autoclaved at $121^{\circ} \mathrm{C}$ for 30 minutes. Flasks were inoculated with $0.5 \mathrm{ml}$ inoculums, prepared by suspending spores from a week old PDA stants in sterile normal saline to contain about $10^{6}$ spores $/ \mathrm{mL}$. The inoculated flasks were incubated at $25^{\circ} \mathrm{C}$ up to 21 days. The supernatants, collected after centrifugation of contents, were used for assaying xylanase.

Enzyme assay: Xylanase activity was assayed by measuring reducing sugars released from xylan. Reaction mixture, consisting of $0.5 \%$ xylan, $0.05 \mathrm{M}$ citrate buffer ( $\mathrm{pH}-4.8$ ), and 50 - $200 \mu \mathrm{l}$ of enzyme preparation in a final volume of $2 \mathrm{ml}$, was incubated for 30 minutes at $50^{\circ} \mathrm{C}$. The liberated reducing sugars were assayed by Somogyi-Nelson method (14). The enzymatic activity was expressed as international units (IUL ${ }^{-1}$ ). One unit of xylanase has been defined as the amount of enzyme that released one micromole of reducing sugars per minute under the assay conditions $\left(\mathrm{pH} 4.8,50^{\circ} \mathrm{C}\right)$.

Optimization of cultural parameters for xylanase production: Cultural conditions were optimized for production of xylanase particularly with respect to incubation period, $\mathrm{pH}$ and temperature, carbon and nitrogen source and concentration of carbon source.
Enzyme was also characterized for optimum $\mathrm{pH}$, temperature and thermostability. Tharmostability of xylanase was determined by measuring the residual activity after exposing the enzyme preperation to various temperatures in the range of $35^{\circ} \mathrm{C}$ to $65^{\circ} \mathrm{C}$ for 15 minutes and then cooled in an ice-bath. The temperature at which the residual activity was reduced to $50 \%$ of the original activity $(\mathrm{Tm})$ was determined by plotting residual activity Vs exposure temperature.

Pretreatment of lignocellulosics: Agricultural wastes contain a good amount of lignin, which protects the xylan to be attacked by hydrolytic enzymes. To make components of lignocellulosics more accessible, substrates were autoclaved with $10 \mathrm{ml}$ of different concentrations of alkali $(0.1,0.5$ and 1.0 N) for $30 \mathrm{~min}$ in $150 \mathrm{ml}$ flasks. After cooling, the alkalinity was neutralized with acid and stock production medium was added to make final volume $30 \mathrm{ml}$ having desired concentrations of nutrients and $\mathrm{pH}$ 4.0. The fermentation was carried out with $T$. viride (S34) for 14 days at $25^{\circ} \mathrm{C}$. The filtrate was used for the estimation of xylanase activity

Saccharification: Saccharification experiment was performed with crude enzyme preparation obtained by fermenting $5 \%$ Jowar for 14 days using $T$ viride (S34). The xylanase and CMCase activities in crude enzyme preparation were 4000 and $480 \mathrm{UL}^{-1}$ respectively. The enzyme concentration used was 0 (control), 0.5 and $1 \mathrm{ml} / \mathrm{g}$ of substrate in the reaction mixture containing $50 \mathrm{mM}$ sodium acetate buffer ( $\mathrm{pH}-5.0)$ in a total volume of $30 \mathrm{ml}$ and $3 \%$ of lignocellulosics in each flask. Each treatment was taken in triplicates. The reaction mixture was incubated at $45^{\circ} \mathrm{C}$ under shaking conditions at $100 \mathrm{rev} \mathrm{min}^{-1}$ up to $72 \mathrm{~h}$ and samples were drawn for the determination of reducing sugars by Somogyi and Nelson method (14).

\section{RESULT AND DISCUSSION}

\section{Optimization of incubation period and medium constituents}

With a view to replace xylan, a costly substrate for xylanase production, various cheap and abundantly available lignocellulosics (maize straw, bajra straw, jowar straw, wheat straw, oat hay and barseem hay) have been tried as carbon sources. Four culture flasks were removed at different time intervals ranging from 7-21 days for determination of xylanase activity. The xylanase production with all the lignocellulosics was found to increase upto 17 days of fermentation period, except with wheat and jowar straw where maximum activity was achieved on $14^{\text {th }}$ day of incubation period (Table 1). Rezende (2002) reported the plateau of xylanase activity from $5^{\text {th }}$ to $14^{\text {th }}$ day for $T$. harzianum using sugarcane bagasse as carbon source (11). Among the various carbon sources, maximum induction was achieved with xylan showing enough activity even at 7 day of incubation period and reached maximum by $17^{\text {th }}$ day. Xylan as the best inducer for xylanase production has also been reported for T. harzianum (1), Aspergillus flavipe (13) and Bacillus 
Table 1. Effect of incubation period on xylanase activity (IUL $\left.{ }^{-1}\right)$ by Trichoderma viride (S34) at $25^{\circ} \mathrm{C}$ using various carbon sources at $1 \%$ level.

\begin{tabular}{lccccc}
\hline \multirow{2}{*}{ Carbon source } & \multicolumn{5}{c}{ Incubation period (Days) } \\
\cline { 2 - 6 } & 7 & 11 & 14 & 17 & 21 \\
\hline Maize straw & 362 & 1429 & 2303 & 2453 & 2008 \\
Bajra straw & 398 & 544 & 1002 & 1510 & 1419 \\
Jowar straw & 938 & 1919 & 2295 & 1600 & 1299 \\
Wheat straw & 245 & 547 & 563 & 387 & 252 \\
Oat hay & 760 & 860 & 1205 & 1215 & 1099 \\
Barseem hay & 159 & 405 & 1049 & 1407 & 1112 \\
Xylan & 2800 & 3590 & 3736 & 4052 & 3706 \\
CMC & 200 & 216 & 239 & 319 & 209 \\
\hline
\end{tabular}

circulans (16). Among the lignocellulosics, maximum induction was achieved with maize straw and jowar straw. This could be attributed to the high hemicellulose content of maize and jowar straw as compared to other lignocellulosics (Table 2). Barseem hay, bajra straw and oat hay were the moderate inducers for xylanase production. Very low level of induction was seen with wheat straw. Wheat straw has also been reported as poor inducer for xylanolytic activity with Bacillus spp $(10,16)$. Carboxy methyl cellulose (CMC), though not the substrate, when used as carbon source also resulted in induction of some xylanase indicating constitutive nature of the enzyme as has also been reported for T. saccharolyticum (12) and T. reesei (18).

In the present study, the effect of nitrogen source was tested by replacing sodium nitrate in medium with other nitrogen sources maintaining equimolar amount of nitrogen. T.viride responded differently to all inorganic (ammonium sulfate, ammonium nitrate, sodium nitrate and ammonium chloride) and organic (urea and peptone) sources (Table 3 ). Inorganic nitrogen sources were better than the organic ones. This may be attributed to the fact that fungus was isolated from soil where inorganic nitrogen is

Table 2. Chemical compositions (\% DM basis) of different lignocellulosics substrates.

\begin{tabular}{lccccc}
\hline Substrates & OM & CP & NDF & ADF & HC \\
\hline Maize straw & 87 & 5 & 80 & 41 & 38 \\
Bajra straw & 89 & 5 & 73 & 50 & 23 \\
Jowar straw & 85 & 5 & 78 & 45 & 32 \\
Wheat straw & 82 & 4 & 76 & 56 & 20 \\
Oat hay & 91 & 10 & 56 & 38 & 18 \\
Barseem hay & 92 & 20 & 45 & 35 & 10 \\
\hline
\end{tabular}

OM - Organic matter; CP - Crude protein; NDF - Neutral detergent fibre; ADF - Acid detergent fibre; HC - Hemicellulose.
Table 3. Effect of different nitrogen sources on xylanase production by T.viride (S34) at $25^{\circ} \mathrm{C}$ and $\mathrm{pH} 4.0$.

\begin{tabular}{cc}
\hline Nitrogen source $(0.05 \% \mathrm{~N} \mathrm{w} / \mathrm{v})$ & Xylanase activity $\left(\mathrm{IUL}^{-1}\right)$ \\
\hline Ammonium Chloride & 2026 \\
Sodium Nitrate & 2506 \\
Ammonium Sulphate & 2239 \\
Ammonium Nitrate & 1599 \\
Urea & 1280 \\
Peptone & 373 \\
\hline
\end{tabular}

used as the $\mathrm{N}$ fertilizer, so it assimilates inorganic nitrogen sources more efficiently as compared to organic ones. Out of inorganic nitrogen sources, $\mathrm{NaNO}_{3}$ was the best nitrogen source followed by $\left(\mathrm{NH}_{4}\right)_{2} \mathrm{SO}_{4}$ and $\mathrm{NH}_{4} \mathrm{Cl}$. Kheng and $\mathrm{Omar}(9)$ also found $\mathrm{NaNO}_{3}$ as the best nitrogen source for xylanase production by local A.niger isolate however their results did not exhibit any significant difference between organic or inorganic nitrogen sources. Moreover, peptone has been reported as the best $\mathrm{N}$ source for xylanase production by Bacillus (10), Streptomyces (11) and Trichoderma viride D3 (19) spp.

\section{Effect of Incubation temperature}

To study the effect of incubation temperature, fungus was grown at various temperatures $\left(20^{\circ} \mathrm{C}\right.$ to $\left.35^{\circ} \mathrm{C}\right)$ using production medium containing $1 \%$ jowar straw as the main carbon source. Maximum xylanase production was observed between temperatures $20-25^{\circ} \mathrm{C}$ (Fig. 1). An optimum temperature of $25^{\circ} \mathrm{C}$ for maximum biomass and xylanase production has also been reported by Simoes and Tauk- Torniseielo for Aspergillus japonicus (21).

\section{Effect of initial pH}

To optimize the xylanase production further, the production media was manipulated by growing the fungus on media with initial $\mathrm{pH}$ ranging from 3.5 to 7.0 . The initial $\mathrm{pH}$ showed a profound influence on xylanase production. The fungus showed maximum production in an acidic $\mathrm{pH}$ of 4.0 and the production decreased with increase in $\mathrm{pH}$ (Fig. 2). Silveira et al (22) found maximum xylanase production for T. harzianum at $\mathrm{pH}$ 5.0. However Rose and Van (18) found highest activity of xylanase enzyme at higher $\mathrm{pH}$ of $5.0-6.0$ using $A$. niger as fungal source. The final $\mathrm{pH}$ of all the production media having different initial $\mathrm{pH}$, increased up to $\mathrm{pH} 7.0$ with the growth and subsequent xylanase production as was also reported by some workers $(13,17)$.

\section{Optimization of Carbon source level}

With a view to further improve the xylanase production without increasing the cost of production, the medium was manipulated with respect to concentration of the lignocellulosics 


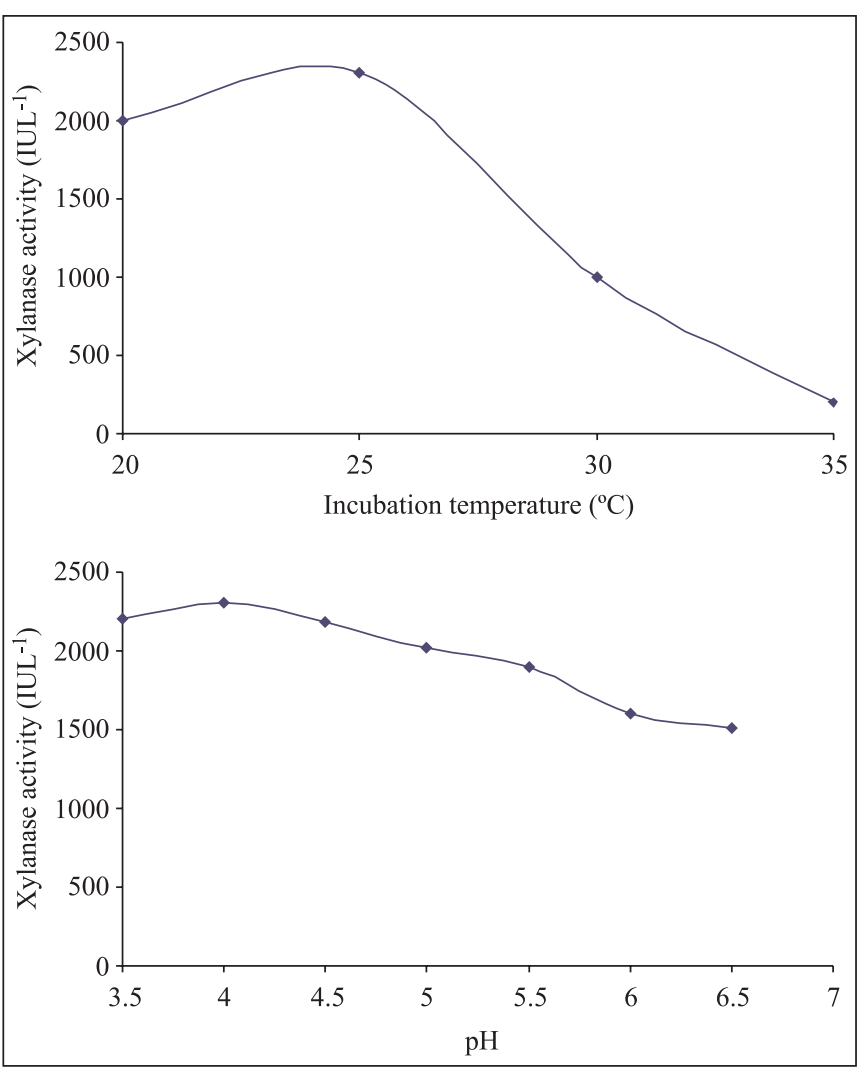

Figure 1. Effect of incubation temperature (Fig. $1 \mathrm{a}$ ) and $\mathrm{pH}$ (Fig. 1b) on xylanase production by T. viride (S34) at $25^{\circ} \mathrm{C}$ using $1 \%$ maize straw as carbon source.

$(2,3,5 \%)$. With increasing concentrations of lignocellulosics in production medium, substantial increase in enzyme production was recorded (Table 4). The best induction for xylanase among the lignocellulosics was again shown with maize straw at 5\% level and was followed by jowar straw \& barseem hay. The induction was even better than that could be achieved by using $3 \%$ pure xylan, the otherwise costly inducer of xylanase. Xylanase production using CMC as carbon source showed seven times increase in the production when its concentration in medium was increased to $3 \%$. Since the xylanase production increased with increase in the lignocellulosics concentration in production medium, further improvement might be achieved by attempting further increasing level of carbon source and reaching up to solid state fermentation.

\section{Effect of pretreatment of lignocellulosics}

A number of reports are available for pre-treatment of lignocellulosics to remove lignin for enhancing xylanase production mainly on wheat straw (23). But as the maize \& jowar straw showed more potential to produce xylanase so the alkali pretreatment and subsequent fermentation was attempted
Table 4. Effect of different concentrations of carbon sources on xylanase production $\left(\mathrm{IUL}^{-1}\right)$ of T.viride $(\mathrm{S} 34)$ at $25^{\circ} \mathrm{C}$ and $\mathrm{pH} 4.0$.

\begin{tabular}{lccc}
\hline \multirow{2}{*}{ Carbon source } & \multicolumn{3}{c}{ Concentration of carbon source (\%) } \\
\cline { 2 - 4 } & 2 & 3 & 5 \\
\hline Maize straw & 5002 & 5982 & 6250 \\
Bajra straw & 1772 & 2097 & 2260 \\
Jowar straw & 3481 & 4675 & 5259 \\
Wheat straw & 1605 & 2485 & 2507 \\
Oat hay & 2018 & 2346 & 2401 \\
Barseem hay & 2807 & 4055 & 4800 \\
Xylan & 3990 & 4251 & $*$ \\
CMC & 1523.3 & 1713.3 & $* *$ \\
\hline
\end{tabular}

* not tried due to dispersibility problem; ** not tried due to high viscosity.

with these two straws. The alkali treatment of jowar and maize straw with $0.1 \mathrm{~N} / 0.5 \mathrm{~N} \mathrm{NaOH}$ resulted in profound increase in xylanase production as compared to respective controls. Pretreatment of jowar and maize straws with $0.1 \% \mathrm{NaOH}$ showed $174 \%$ and $230 \%$ increase in xylanase production over their respective controls. Whereas treatment with $0.5 \mathrm{~N} \mathrm{NaOH}$ resulted in $204 \%$ and $280 \%$ increase in xylanase production. However with more severe treatment $(1.0 \mathrm{~N} \mathrm{NaOH})$, the xylanase production was almost reduced to half with either of the straws as compared to control. This can be attributed to the decomposition of xylan with severe alkali treatment (Table 5). Moreover at higher severity of $\mathrm{NaOH}$, more by products like furfurals are formed which may make the medium somewhat harder to ferment (4).

\section{Enzyme characteristics}

Xylanase, produced from T.viride on various lignocellulosics in submerged culture fermentation $(\mathrm{SmF})$, showed optimum temperature from $45-55^{\circ} \mathrm{C}$ and had a broad $\mathrm{pH}$ optima range with a peak at $\mathrm{pH}$ 4.8. The temperature $(\mathrm{Tm})$ at which the residual activity was reduced to $50 \%$ of the original activity was found to e $50^{\circ} \mathrm{C}$, indicating it to be a reasonably thermostable.

Table 5. Effect of alkali treated roughages (1\%) on xylanase production at $\mathrm{pH} 4.0$ on $14^{\text {th }}$ day of incubation period.

\begin{tabular}{lcc}
\hline \multirow{2}{*}{ Treatment } & \multicolumn{2}{c}{ Xylanase activity $\left(\mathrm{IUL}^{-1}\right)$} \\
\cline { 2 - 3 } & Jowar straw & Maize straw \\
\hline Control & 2293 & 2000 \\
$0.1 \mathrm{~N} \mathrm{NaOH}$ & 4000 & 4625 \\
$0.5 \mathrm{~N} \mathrm{NaOH}$ & 4693 & 5750 \\
$1.0 \mathrm{~N} \mathrm{NaOH}$ & 1120 & 1002 \\
\hline
\end{tabular}




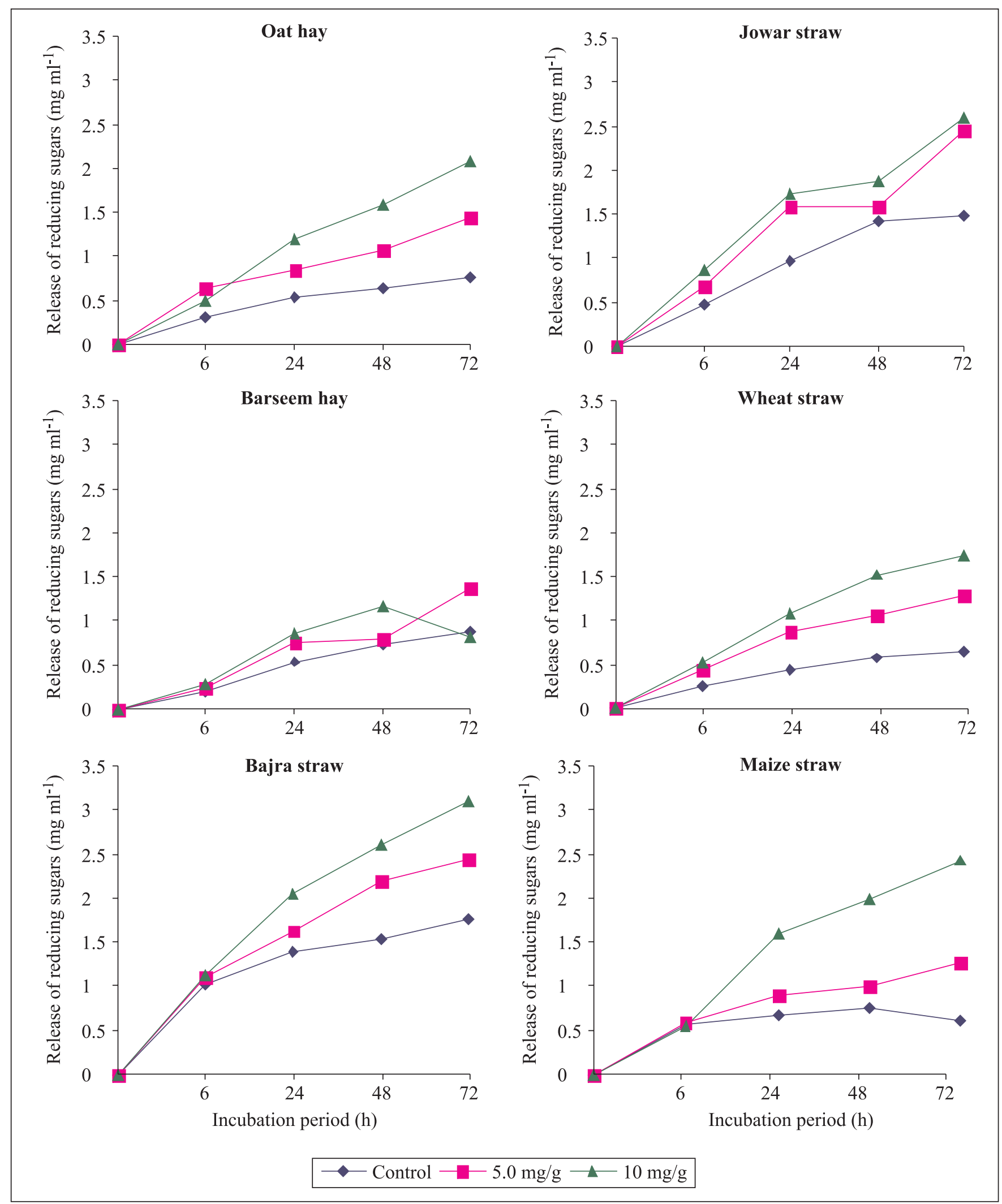

Figure 2. Saccharification of different lignocellulosic substrates with fibrolytic enzymes at 0 (control $\bullet), 0.5 \mathrm{ml} \mathrm{g}^{-1}(\boldsymbol{\Delta}) \mathrm{or} 1 \mathrm{ml} \mathrm{g}^{-1}($ 


\section{Saccharification}

Efficiency of enzyme preparation for saccharification of xylan of various lignocellulosics was determined. Saccharification of various lignocellulosics was carried out at $45^{\circ} \mathrm{C}$ in $50 \mathrm{mM}$ sodium acetate buffer ( $\mathrm{pH}$ 5.0) for $72 \mathrm{~h}$ using agro residues with initial concentration of $3.0 \mathrm{gdL}^{-1}$. The hydrolysis was carried out for $72 \mathrm{~h}$ and samples were withdrawn periodically for analysis of reducing sugars. Release of reducing sugars increased with increase in incubation period. All the lignocellulosics, used for saccharification, were found to be susceptible for enzymatic hydrolysis as shown by a significant increase in the production of reducing sugars when treated with 0.5 or $1 \mathrm{ml}$ enzyme $/ \mathrm{g}$ of fibre as compared to controls (Fig. 3). A positive correlation between saccharification and hemicellulose content was observed. Maize, jowar and bajra, having high hemicellulolytic material (Table 2), were found to be more susceptible for enzymatic hydrolysis when compared with the other agrowastes. Barseem showed more resistance to enzymatic hydrolysis.

Thus it can be concluded from the present study that the production of xylanase can be made cost effective by using maize and jawar straw as carbon source. The xylanase production can further be improved by pretreating the straw with $0.5 \mathrm{~N} \mathrm{NaOH}$ which make the xylan more accessible for attack by fungus by removing lignin.

\section{ACKNOWLEDGEMENT}

Authors thank Council of Scientific and Industrial Research (CSIR), Govt. of India for financial assistance.

\section{RESUMO}

\section{Produção de xilanase com resíduos lignocelulósicos ricos em xilana por uma cepa local de Trichoderma viride isolada de solo}

Neste estudo, otimizou-se as condições culturais e nutricionais para produção aumentada de xilanase por uma cepa local de Trichoderma viride isolada de solo, empregando-se vários substratos lignocelulósicos, em fermentação submersa. Entre os substratos utilizados, o melhor indutor de produção de xilanase foi palha de milho, seguido de palha de sorgo. A atividade mais alta foi obtida entre 14 e 17 dias de fermentação. Com palha de milho observou-se um aumento contínuo na produção de xilanase com o aumento da concentração dos substratos lignocelulósicos no meio, sendo que a melhor atividade foi obtida com $5 \%$ de palha de milho. A produção de xilanase com níveis mais altos de (3 a 5\%) de milho, sorgo e forragem verde (barseem) foi mais levada do que com xilana comercial como fonte de carbono. Entre as fontes de nitrogênio testadas, a melhor foi nitrato de sódio. Produção máxima de xilanase foi obtida quando o $\mathrm{pH}$ inicial do meio foi 3,5-4,0 e a temperatura de incubação $25^{\circ} \mathrm{C}$. A enzima foi eficiente na sacarificação de diferentes substratos lignocelulósicos. A produção de xilanase poderia ser aumentada empregando-se álcali ao invés de palha tratada como fonte de carbono.

Palavras-chave: Produção de xilanase, Trichoderma viride, substratos lignocelulósicos, fermentação submersa.

\section{REFERENCES}

1. Ahmed, S.; Quart, A.; Night, A.; Saima, N.; Spayed, R.; Amery, J. (2003) Induction of xylanase and cellulose genes from Trichoderma harzianum with different carbon sources. Pak. J. Biol. Sic., 6, 1912-1916.

2. Alfani, F.; Gallifuoco, A.; Saporosi, A.; Spera, A.; Cantarella, M. (2000) Comparison of SHF and SSF processes for bioconversion of steam-exploded wheat straw. J. Induct. Microbial. Biotechnol., 25, 192-194.

3. AOAC. 1990. Official Method of Analysis. $15^{\text {th }}$ edn Washington, DC. pp. 69-84.

4. Gable, M.; Zacchi, G. (2002). A review of the production of ethanol from softwood. Appl. Biochem. Biotechnol., 59, 618-628.

5. Gawande, P.V.; Kamat, M.Y. (1999). Production of Aspergillus xylanase by lignocellulosic waste fermentation and its application. J. Appl. Microbiol., 87, 511-519.

6. Gessesse, A.; Gashe, B.A. (1997). Production of alkaline xylanase by an alkaliphilic Bacillus sp. isolated from an alkaline soda lake. $J$. Appl. Microbiol., 83, 402-406.

7. Gomes, I.; Gomes, J.; Steines, W.; Esterbaner, H. (1992) Production of cellulase and xylanase by a wild strain of Trichoderma viride. Appl. Microbiol. Biotechnol., 36, 701-707.

8. Gutierrez-Correa, M.; Tengerdy, R.P. (1998). Xylanase production by fungal mixed culture solid substrate fermentation on sugar cane bagasse. Biotechnol. Lett., 20, 45-47.

9. Kheng, P.P.; Omar, I.C. (2005). Xylanase production by a local fungal isolate, Aspergillus niger USM AI 1 via solid state fermentation using palm kernel cake (PKC) as substrate. Songklanakarin J. Sci. Technol., 27, 325-336.

10. Kuhad, R.C.; Chopra, P.; Battan, B.; Kapoor, M.; Kuhar, S. (2006). Production, partial purification and characterization of a thermo alkali stable xylanase from Bacillus sp. RPP-1. Indian J. Microbiol., $46,13-23$.

11. Kuhad, R.C.; Kapoor, M.; Chaudhary, K. (2006). Production of xylanase from Streptomyces sp. M-83 using cost-effective substrates and its application in improving digestibility of monogastric animal feed. Indian J. Microbiol., 46, 109-119.

12. Lee, Y.E.; Lowe, S.E.; Zeikus, J.G. (1993). Regulation and characterization of xylanolytic enzymes of Thermoanaerobacterium saccharolyticum B6A-R1. Appl. Environ. Microbiol., 59, 763-771.

13. Mukhopadhay, S.K.; Paul, S.; Roy, A.; Chatterjee, S.P. (1997). Xylanolytic enzyme production by Aspergillus flavipe. Indian J. Microbiol., 37, 77-80.

14. Nelson, N.A. (1944). Photometric adaptation of somogyi method for the determination of glucose. J. Biol. Chem., 153, 375-380.

15. Ninawe, S.; Kuhad, R.C. (2005). Use of xylan rich cost effective agro-residues in the production of xylanase by Streptomyce cyaneus SN 32. J. Appl. Microb., 99, 1141-1148.

16. Qureshy, A.F.; Khan, L.A.; Khanna, S. (2002). Cloning, regulation and purification of cellulase free xylanase from Bacillus circulans Teri-42. Indian. J. Microbiol., 42, 35-41.

17. Rezende, M.I.; Barbosa, A.M.; Vasconcelos, A.F.D.; Endo, A.S. (2002). Xylanase production by Trichoderma harzianum rifai by 
solid state fermentation on sugarcane bagasse. Braz. J. Microbiol., 33, 67-72

18. Rose, S.H.; Van, Z.W. (2004). Constitute expression of Trichoderma reesei beta 1, 4 xylanase gene (xyn 2 ) and the beta $-1,4$ endoglucanase gene. (eg 1) in Aspergillus niger in molasses and defined glucose media. Appl. Microbiol. Biotechnol., 58, 461-468. www.springlink.com/index/H12322144V2N2331.pdf.

19. Seyis, I.; Aksoz, N. (2005 a). Xylanase production from Trichoderma viride 1073 D3 with alternative carbon and nitrogen sources. Food Technol. Biotechnol., 43, 37-40.

20. Seyis, I.; Aksoz, N. (2005 b). Investigations of factors affecting xylanase activity from Trichoderma herzianum 1073 D31. Braz. Arah Biol. Technol., 148, 187-93.

21. Simoes, M.L.G.; Tauk - Torniseielo, S.M. (2006). Optimization of xylanase biosynthesis by Aspergillus japonicus isolated from a 'Caatinga' area in the Brazilian state of Bahia. African J. Biotechnol., $5,1135-1141$
22. Silveira, F.Q.P.; Ximenes, F.A.; Cacais, A.O.G.; Milagres, A.M.F.; Mederros, C.L.; Puls, J.E.; Filno, E.X.F. (1999). Hydrolysis of xylans by enzyme system from solid cultures of Trichoderma harzianum strains. Braz. J. Med. Biol. Res., 32, 947-952.

23. Szodrak, J. (1988). Production of cellulases and xylanase by Trichoderma reesei F-522 on pretreated wheat straw. Acta. Biotechnol., 8, 509-515.

24. Van-Soest, P.J. (1983). Nutritional ecology of the ruminants. OQB Books, Corvallis, Oregon pp. 1-373.

25. Wallace, R.J.; Wallace, N.M.; Nsereko, V.L.; Hartnell, G.F. (2001). Influence of supplementary fibrolytic enzymes on the fermentation of corn and grass silage by mixed ruminal microorganisms in vitro. $J$. Anim. Sci., 79, 1905-1916

26. Yinbo, Q.; Peizi, G.; Dong, W.; Xin, Z.; Xiao, R. (1996). Production, charaterisation and application of the cellulase free xylanase from Aspergillus niger. Appl. Biochem. Biotechnol., 57/58, 375-381. 